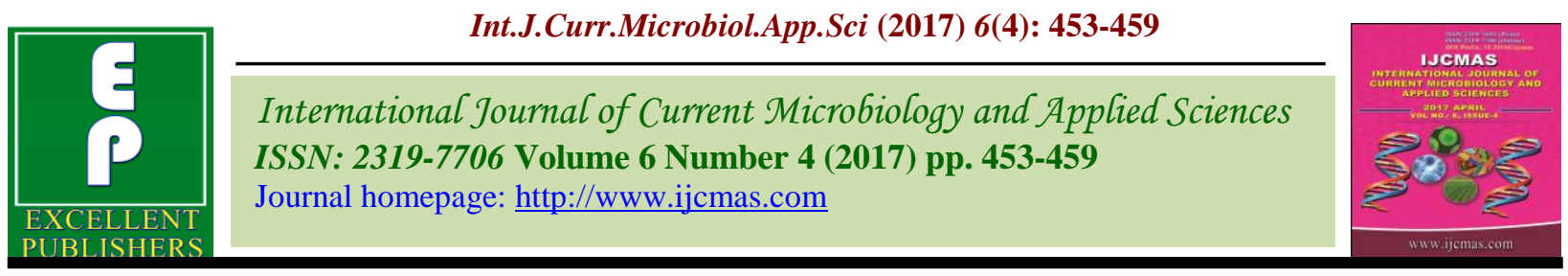

Original Research Article

https://doi.org/10.20546/ijcmas.2017.604.052

\title{
Integrated Nutrient Management on Growth, Quality, Yield and Soil Fertility of Gladiolus in Lower Gangetic Plain of India
}

\author{
Rubina Khanam*, Dipa Kundu and S.K. Patra \\ Department of Agricultural Chemistry and Soil Science, Bidhan Chandra Krishi Viswavidyalaya, \\ Mohanpur, Nadia-741 252, West Bengal, India \\ *Corresponding author
}

\section{A B S T R A C T}

Keywords

Gladiolus hybridus, Inorganic fertilizers, Flower yield, Soil fertility, Vermicompost.

Article Info

Accepted:

02 March 2017

Available Online:

10 April 2017
A field experiment was carried out at the Central Research Farm, Bidhan Chandra Krishi Viswavidyalaya, Nadia, West Bengal representing the lower Gangetic plain of India during the winter seasons of 2011-'12, 2012-'13 and 2013-'14 on integrated nutrient management of inorganic fertilizers and organic manure on growth, floral attributes and yield of Gladiolus hybridus. Maximum flower yield (9731 kg/ha), number of corms per plant (3.5), growth and quality parameters was recorded with integration of $50 \%$ recommended dose of chemical fertilizers (RDF) with vermicompost @ 2.5 ton/ha. The build-up of available $\mathrm{N}, \mathrm{P}$ and $\mathrm{K}$ in soil and consequent higher plant leaf nutrients was also detected with $50 \%$ RDF + vermicompost @ 2.5 ton/ha. In contrast, minimum growth, quality parameters, less number of corms per plant and flower yield, lower plant leaf nutrients and higher depletion of available $\mathrm{N}, \mathrm{P}$ and $\mathrm{K}$ in soil were observed under unfertilized control treatment. Thus the conjunctive use of $50 \%$ RDF with vermicompost @ 2.5 ton/ha may be recommended for improving the quality and productivity of G. hybridus and improvement of available N, $\mathrm{P}$ and $\mathrm{K}$ status in soil.

\section{Introduction}

Gladiolus hybridus is one of the most popular ornamental bulbous plants grown in many parts of the world for its dazzling florets colour, sturdy spike, size, attractive appearance and keeping quality. At present, the productivity and quality of gladiolus in the international market are declining considerably due to climatic aberrations and mismanagement of soil and nutritional factors. The inadequate and imbalanced use of inorganic fertilizers accompanied with the restricted use of organic manures adversely affects the growth and yield of plant (Singh $e t$ al., 2011). Simultaneously, prolonged chemical fertilization resulted in yield reduction, soil health deterioration, water pollution and increasing disease and pest infestation (Okwuagwu et al., 2003). The supplementary and complementary use of organic manures and inorganic chemical fertilizers remains the alternative choice of growers for sustainable production and maintaining the soil health (Singh and Pandey, 2006). The vermicompost is an excellent source of organic matter which not only supplies macro- and micronutrients to plants, but also improves the physical, chemical and biological properties of soil (Sinha and Sunil, 2009). The plants require both organic manures and inorganic fertilizers 
in adequate amounts and in right combination to promote better yield and quality of produce. The objective of the present study was to evaluate the response of Gladiolus hybridus to integrated nutrient management using organic manure (vermicompost) and inorganic fertilizers on the growth, floral characteristics, flower yield, leaf nutrients contents and soil fertility improvement as regards to available $\mathrm{N}$. $\mathrm{P}$ and $\mathrm{K}$ in soil.

\section{Materials and Methods}

The field experiments were conducted during the winter seasons of 2011-'12, 2012-'13, 2013-'14 at the Central Research Farm, Bidhan Chandra Krishi Viswavidyalaya under the jurisdiction of lower Gangetic plain of West Bengal, India to study the response of integrated nutrient management on Gladiolus hybridus cv. American beauty. The site is located between $23^{\circ} \mathrm{N}$ latitude and $89^{\circ} \mathrm{E}$ longitude at an altitude of $9.75 \mathrm{~m}$ above the mean sea level. The study area falls under sub-humid tropic characterized by hot dry summer months (May-June) and cold winter (December-January). The average temperature ranges between 37.6 and $25.4{ }^{\circ} \mathrm{C}$ in summer and between 23.7 and $10.5{ }^{\circ} \mathrm{C}$ in winter. The soil was sandy loam in texture (Typic Fluvaquept). The physical and chemical properties of the experimental soil are presented in tables 1 and 2 . The available $\mathrm{N}, \mathrm{P}$ and $\mathrm{K}$ in $0-15$ and $15-30 \mathrm{~cm}$ depths of soil profile were 158.3 and $140.5 ; 23.9$ and 21.6 and 141.5 and $127.3 \mathrm{~kg} / \mathrm{ha}$, respectively. The net plot dimension was $3.0 \mathrm{~m} \times 1.0 \mathrm{~m}$ leaving $0.5 \mathrm{~m}$ bund width and $1.0 \mathrm{~m}$ irrigation channel. The experiment consisted of four treatments viz., $\mathrm{T}_{1}$ : control (without fertilizers and manure), $\mathrm{T}_{2}: 100: 60: 60 \mathrm{~kg}$ NPK/ha, $\mathrm{T}_{3}$ : 50:30:30 kg NPK/ha + vermicompost@ 2.5 ton/ha and $\mathrm{T}_{4}$ : vermicompost @ 5 ton/ha each replicated four times was laid out in a randomized block design. The recommended fertilizer doses of 100:60:60 kg NPK/ha were applied in form of urea, muriate of potash and single superphosphate for $\mathrm{N}, \mathrm{P}$ and $\mathrm{K}$, respectively. The organic source of fertilizer i.e. vermicompost containing $\mathrm{N} 2.1 \%, \mathrm{P}$ $1.25 \%, \mathrm{~K} 1.07 \%$, Ca 1.4\%, Zn 350 ppm, Mn 294 ppm, $\mathrm{Cu} 237$ ppm was incorporated in the soil during the final land preparation. Full dose of phosphorus and potassium and onethird of nitrogen was applied as basal as per treatments. The remaining two-third of nitrogen was applied in two equal splits at interval of 30 and 60 days after application of basal dose. Medium sized corms were planted during second week of November each year in lines maintaining row and plant spacing of 30 and $25 \mathrm{~cm}$, respectively at a depth of $5 \mathrm{~cm}$. Flower was harvested 5-times between mid January and first week of February. The growth and flowering parameters, corms and flower yield data were recorded. The soil samples at 0-15 and 15-30 cm depth were collected before and after harvest of plant. Plant leaf samples were also collected at seedling, flowering and harvesting stages i.e. at 30,60 and 90 days after planting. These samples were processed and analyzed for physical and chemical properties and available $\mathrm{N}, \mathrm{P}$ and $\mathrm{K}$ for soils and plant leaf concentrations for $\mathrm{N}, \mathrm{P}$, and $\mathrm{K}$ following the standard procedures (Jackson, 1973). The data obtained were subjected to the proper statistical analysis (Gomez and Gomez, 1984).

\section{Results and Discussion}

\section{Growth parameters}

Application of inorganic fertilizers and organic manure either alone or, their combination had significant effect in improving the growth characters of plants over control without manure and fertilization (Table 3). Among the different treatments, the conjunctive use of 50\% RDF + vermicompost @ 2.5 ton/ha $\left(\mathrm{T}_{3}\right)$ recorded the maximum 
plant height $(54.3 \mathrm{~cm})$, minimum days to corm sprouting (12.6), maximum number of leaves per plant (11.9) and maximum length of longest leaf per plant $(38.3 \mathrm{~cm})$, which was superior to that with the sole application of $100 \%$ RDF $\left(\mathrm{T}_{2}\right)$ or, vermicompost $\left(\mathrm{T}_{4}\right)$. This implies that the integration of both easily available inorganic fertilizers and slowly available organic manure in supplying macronutrients are essential for enhancing the plant growth parameters. These results are competitive with the findings of Singh et al., (2013) who reported the higher plant height, number of leaves per plant, length of longest leaf per plant and minimum days to sprouting were obtained with $50 \%$ RDF (NPK 150:100:100 kg/ha) + vermicompost (2 ton/ha). The consistent supply of $\mathrm{N}, \mathrm{P}$ and $\mathrm{K}$ through integrated nutrient management may play a vital role in promoting growth and development of plant and thus resulted in higher growth attributes (Sharma and Singh, 2007). Similarly, maximum number of corms (3.5) and cormlets (12.1) per plant was also obtained in $\mathrm{T}_{3}$ treatment followed by $\mathrm{T}_{2}$ and $\mathrm{T}_{4}$, respectively. The beneficial effect of integrated nutrient management on the improvement of growth parameters and enhanced corms and cormlets per plant might be ascribed to the higher and steady supply of easily available NPK nutrients provided with some essential micronutrients and growth promoting substances through vermicompost throughout the growth stages (Singh et al., 2013). On the other hand, minimum number of corms and cormlets per plant (2.3 and 8.4, respectively) was noticed in control treatment receiving no extraneous supply of NPK nutrients.

\section{Floral parameters}

The organic and inorganic sources of nutrients either sole or, their combined application recorded positive significance influence on different floral parameters of plants over control (Table 4). However, the integration of $50 \% \mathrm{RDF}+2.5$ ton/ha of vermicompost $\left(\mathrm{T}_{3}\right)$ significantly increased the spikes/plot (68.7), number of florets per spike (9.6), longer spike length $(63.3 \mathrm{~cm})$, weight of single spike (42.8 g), diameter of flower (8.5 $\mathrm{cm}$ ), longevity of spike (20.6 days) and vase life of flower at room temperature (19.7 days) and was superior to that of $100 \% \operatorname{RDF}\left(\mathrm{T}_{2}\right)$ and vermicompost addition $\left(\mathrm{T}_{4}\right)$. The results are in close conformity with the findings of with Kabir et al., (2011) who had reported that floral characters like bulb length, bulb diameter, bulb yield, rachis length, spike length and diameter and number of florets per spike in Polianthes tuberose were greater in organic fertilizers supplemented with half chemical fertilizers than absolute use of chemical fertilizers. The incorporation of organic manure like vermicompost with chemical fertilizers thus greatly helped in improving the flower attributes. This was most probably due to the increased availability of macro- and micronutrients in the soil and increased level of growth promoting substances which resulted in better plant vigour and enhanced uptake of nutrients and water by plants (Patel et al., 1997).

\section{Flower yield}

The addition of inorganic and organic sources nutrients and their combination had pronounced effect on the flower yields of gladiolus over the control in all the three years (Table 5). Maximum yield was obtained with 50\% RDF in conjunction with vermicompost@2.5 ton/ha $\left(\mathrm{T}_{3}\right)$ and was found superior to the remaining treatments. These results are in consistent with the findings of Padaganur et al., (2010) and Kabir et al., (2011) who observed the significantly higher flower yield in Polianthes tuberose with organic fertilizers enriched with half chemical fertilizers than recommended chemical fertilizers only. This implies that the 
combined application of inorganic fertilizers and organic manure was more effective in enhancing the yield contributing characters which resulted in higher flower yield, possibly due to the increased availability of primary and secondary nutrients in soil during the entire crop growth period and their subsequent uptake by the plants. In addition, the integrated nutrient supply involving organic and inorganic components resulted in greater stimulation of the rates of various physiological and metabolic processes leading to better plant growth and floral characteristics and ultimately flower yield (Singh et al., 2013). Application of vermicompost manure registered low flower yields, thereby suggesting that vermicompost alone could not sustain high flower yield probably due to slow release of nutrients in lower amounts during the vegetative and reproductive growth stages of the plants.

Table.1 Physical properties of the experimental field soil

\begin{tabular}{|c|c|c|c|c|c|c|}
\hline $\begin{array}{c}\text { Depth } \\
(\mathrm{cm})\end{array}$ & $\begin{array}{c}\text { Sand } \\
(\%)\end{array}$ & $\begin{array}{c}\text { Silt } \\
(\%)\end{array}$ & $\begin{array}{c}\text { Clay } \\
(\%)\end{array}$ & $\begin{array}{c}\text { Bulk Density } \\
\left(\mathrm{g} / \mathrm{cm}^{3}\right)\end{array}$ & $\begin{array}{c}\mathrm{HC} \\
(\mathrm{cm} / \mathrm{hr})\end{array}$ & WHC (\%) \\
\hline $0-15$ & 70.2 & 14.4 & 15.5 & 1.47 & 2.74 & 49.0 \\
\hline $15-30$ & 68.1 & 15.2 & 16.7 & 1.51 & 2.18 & 50.2 \\
\hline
\end{tabular}

Table.2 Chemical properties of the experimental soil

\begin{tabular}{|c|c|c|c|c|c|c|}
\hline $\begin{array}{c}\text { Depth } \\
(\mathrm{cm})\end{array}$ & $\begin{array}{c}\mathrm{pH} \\
(1: 2.5)\end{array}$ & $\begin{array}{c}\mathrm{EC} \\
(\mathrm{dS} / \mathrm{m})\end{array}$ & $\begin{array}{c}\text { Organic } \\
\text { Carbon (\%) }\end{array}$ & $\begin{array}{c}\text { Available } \\
\mathrm{N}(\mathrm{kg} / \mathrm{ha})\end{array}$ & $\begin{array}{c}\text { Available } \\
\mathrm{P}(\mathrm{kg} / \mathrm{ha})\end{array}$ & $\begin{array}{c}\text { Available K } \\
(\mathrm{kg} / \mathrm{ha})\end{array}$ \\
\hline $0-15$ & 6.8 & 0.1 & 0.46 & 158.3 & 23.9 & 141.5 \\
\hline $15-30$ & 6.38 & 0.08 & 0.4 & 140.5 & 21.6 & 127.3 \\
\hline
\end{tabular}

Table.3 Effect of integrated nutrient management on growth parameters and corms yield of Gladiolus hybridus (pooled over 2011-'12, 2012-'13, 2013-'14)

\begin{tabular}{|c|c|c|c|c|c|c|}
\hline Treatments & $\begin{array}{c}\text { Plant } \\
\text { Height } \\
(\mathrm{cm})\end{array}$ & $\begin{array}{c}\text { Number } \\
\text { of } \\
\text { Leaves }\end{array}$ & $\begin{array}{c}\text { Largest Leaf } \\
\text { Length } \\
(\mathrm{cm})\end{array}$ & $\begin{array}{c}\text { Days to } \\
\text { Sprouting }\end{array}$ & $\begin{array}{c}\text { No. of } \\
\text { Corms } \\
\text { /Plant }\end{array}$ & $\begin{array}{c}\text { No. of } \\
\text { Cormlets/ } \\
\text { Plant }\end{array}$ \\
\hline $\begin{array}{c}\mathrm{T}_{1}=\text { Control (without } \\
\text { Manure and Fertilizer) }\end{array}$ & 49.1 & 10.1 & 35.8 & 14.4 & 2.3 & 8.4 \\
\hline $\mathrm{T}_{2}=100 \%$ RDF & 53.2 & 11.2 & 37.9 & 13.2 & 3.2 & 10.9 \\
\hline $\begin{array}{c}\mathrm{T}_{3}=50 \% \text { RDF + VC } \\
\text { @ 2.5 ton/ha }\end{array}$ & 54.3 & 11.9 & 38.3 & 12.6 & 3.5 & 12.1 \\
\hline $\mathrm{T}_{4}=\mathrm{VC} @ 5$ ton/ha & 51.5 & 10.7 & 37.4 & 13.8 & 2.8 & 9.2 \\
\hline $\mathrm{CD}(5 \%)$ & 1.2 & 0.5 & 0.8 & 0.4 & 0.3 & 0.9 \\
\hline
\end{tabular}

RDF: Recommended dose of fertilizers, VC: Vermicompost 
Table.4 Effect of integrated nutrient management on floral parameters of Gladiolus hybridus (pooled over 2011-'12, 2012-'13, 2013-'14)

\begin{tabular}{|c|c|c|c|c|c|c|c|}
\hline Treatments & $\begin{array}{c}\text { No. of } \\
\text { Spikes } \\
\text { /Plot }\end{array}$ & $\begin{array}{c}\text { No. of } \\
\text { Florets } \\
\text { /Spike }\end{array}$ & $\begin{array}{c}\text { Spike } \\
\text { Length } \\
(\mathrm{cm})\end{array}$ & $\begin{array}{c}\text { Wt. of a } \\
\text { Single } \\
\text { Spike(g) }\end{array}$ & $\begin{array}{c}\text { Diameter } \\
\text { of Flower } \\
(\mathrm{cm})\end{array}$ & $\begin{array}{c}\text { Longevity } \\
\text { of Spike } \\
\text { (days) }\end{array}$ & $\begin{array}{c}\text { Vas Life of Cut } \\
\text { Flower at Room } \\
\text { Temperature (days) }\end{array}$ \\
\hline $\begin{array}{c}\mathrm{T}_{1}=\text { Control } \\
\text { (without } \\
\text { Manure and } \\
\text { Fertilizer) }\end{array}$ & 58.4 & 7.4 & 56.4 & 38.1 & 7.3 & 18.5 & 17.1 \\
\hline $\begin{array}{c}\mathrm{T}_{2}=100 \% \\
\text { RDF }\end{array}$ & 66.2 & 8.8 & 61.8 & 41.4 & 8.1 & 20.1 & 18.8 \\
\hline $\begin{array}{c}\mathrm{T}_{3}=50 \% \text { RDF } \\
+ \text { VC @ 2.5 } \\
\text { ton/ha }\end{array}$ & 68.7 & 9.6 & 63.3 & 42.8 & 8.5 & 20.6 & 19.7 \\
\hline $\begin{array}{c}\mathrm{T}_{4}=\mathrm{VC} @ 5 \\
\text { ton/ha }\end{array}$ & 61.8 & 8.2 & 59.3 & 39.6 & 7.8 & 19.2 & 17.9 \\
\hline CD (5\%) & 2.3 & 0.6 & 1.1 & 0.9 & 0.3 & 0.4 & \\
\hline
\end{tabular}

Table.5 Effect of integrated nutrient management on flower yield of Gladiolus hybridus during 2011-'12, 2012-'13, 2013-'14

\begin{tabular}{|c|c|c|c|c|}
\hline Treatments & \multicolumn{3}{|c|}{ Flower Yield (kg/ha) } \\
\cline { 2 - 4 } & $2011-^{`} 12$ & $2012-^{`} 13$ & $2013-^{`} 14$ & Mean \\
\hline $\mathrm{T}_{1}=$ Control (without Manure and Fertilizer) & 8114 & 8034 & 8151 & 8110 \\
\hline $\mathrm{T}_{2}=100 \%$ RDF & 9155 & 8965 & 9643 & 9254 \\
\hline $\mathrm{T}_{3}=50 \%$ RDF + VC @ 2.5 ton/ha & 9592 & 9428 & 10174 & 9731 \\
\hline $\mathrm{T}_{4}=$ VC @ 5 ton/ha & 8467 & 8572 & 8695 & 8586 \\
\hline CD (5\%) & 322 & 363 & 407 & 384 \\
\hline
\end{tabular}

Table.6 Available N, P and K contents at two depths of soil profile as influenced by integrated nutrient management on Gladiolus hybridus

\begin{tabular}{|c|c|c|c|c|c|c|}
\hline \multirow[t]{3}{*}{ Treatments } & \multicolumn{2}{|c|}{$\begin{array}{l}\text { Available N } \\
(\mathrm{kg} / \mathrm{ha})\end{array}$} & \multicolumn{2}{|c|}{$\begin{array}{c}\text { Available P } \\
(\mathrm{kg} / \mathrm{ha})\end{array}$} & \multicolumn{2}{|c|}{$\begin{array}{l}\text { Available K } \\
\text { (kg/ha) }\end{array}$} \\
\hline & \multicolumn{6}{|c|}{ Soil Depth $(\mathrm{cm})$} \\
\hline & $0-15$ & $15-30$ & $0-15$ & $15-30$ & $0-15$ & $15-30$ \\
\hline $\begin{array}{l}\mathrm{T}_{1}=\text { Control (without } \\
\text { Manure and Fertilizer) }\end{array}$ & 142.2 & 135.4 & 20.2 & 19.3 & 128.2 & 122.7 \\
\hline $\mathrm{T}_{2}=100 \% \mathrm{RDF}$ & 166.1 & 155.8 & 25.6 & 22.2 & 143.4 & 135.3 \\
\hline $\begin{array}{c}\mathrm{T}_{3}=50 \% \mathrm{RDF}+\mathrm{VC} @ 2.5 \\
\text { ton } / \mathrm{ha}\end{array}$ & 172.4 & 161.3 & 26.1 & 23.7 & 145.7 & 137.5 \\
\hline $\mathrm{T}_{4}=\mathrm{VC} @ 5$ ton/ha & 148.9 & 142.6 & 22.8 & 21.5 & 138.6 & 130.6 \\
\hline $\mathrm{CD}(5 \%)$ & 5.8 & 6.2 & 1.3 & 0.9 & 2.7 & 4.1 \\
\hline
\end{tabular}


Table.7 Plant nutrient concentration at vegetative, flowering and harvesting stages of Gladiolus hubridus as influenced by integrated nutrient management

\begin{tabular}{|c|c|c|c|c|c|c|c|c|c|}
\hline \multirow{2}{*}{ Treatments } & \multicolumn{3}{|c|}{ Plant N (\%) } & \multicolumn{3}{c|}{ Plant P (\%) } & \multicolumn{3}{c|}{ Plant K (\%) } \\
\cline { 2 - 10 } & $\mathrm{V}$ & $\mathrm{F}$ & $\mathrm{H}$ & $\mathrm{V}$ & $\mathrm{F}$ & $\mathrm{H}$ & $\mathrm{V}$ & $\mathrm{F}$ & $\mathrm{H}$ \\
\hline $\begin{array}{c}\mathrm{T}_{1}=\text { Control (without Manure } \\
\text { and Fertilizer) }\end{array}$ & 1.10 & 1.28 & 1.20 & 0.42 & 0.46 & 0.43 & 2.48 & 2.72 & 2.40 \\
\hline $\mathrm{T}_{2}=100 \%$ RDF & 1.46 & 1.36 & 1.31 & 0.56 & 0.52 & 0.49 & 2.63 & 2.83 & 2.72 \\
\hline $\begin{array}{c}\mathrm{T}_{3}=\text { 50\% RDF + VC @ 2.5 } \\
\text { ton/ha }\end{array}$ & 1.48 & 1.64 & 1.41 & 0.60 & 0.58 & 0.54 & 2.87 & 3.12 & 2.78 \\
\hline $\mathrm{T}_{4}=$ VC @ 5 ton/ha & 1.20 & 1.31 & 1.27 & 0.44 & 0.49 & 0.45 & 2.54 & 2.76 & 2.46 \\
\hline $\mathrm{CD}$ (5\%) & 0.04 & 0.03 & 0.07 & 0.02 & 0.02 & 0.02 & 0.08 & 0.08 & 0.09 \\
\hline
\end{tabular}

$\mathrm{V}$ : vegetative stage, $\mathrm{F}$ : flowering stage, $\mathrm{H}$ : harvesting stage

\section{Soil fertility}

Available N, P and $\mathrm{K}$ status in surface and subsurface layers of soil after harvest of gladiolus plants was significantly influenced by the application of inorganic fertilizers, organic manure (vermicompost) and their combination compared with the control (Table 6). Maximum improvement in the available $\mathrm{N}, \mathrm{P}$ and $\mathrm{K}$ nutrients was recorded by integrating the use of $50 \%$ recommended dose of fertilizers (RDF) with 2.5 ton/ha of vermicompost $\left(\mathrm{T}_{3}\right)$, followed by that of $100 \% \operatorname{RDF}\left(\mathrm{T}_{2}\right)$. Conversely, minimum values of available $\mathrm{N}, \mathrm{P}$ and $\mathrm{K}$ status in soil layers at post-harvest was found under unfertilized control treatment $\left(\mathrm{T}_{1}\right)$, indicating the depletion of reserve soil nutrients as compared to the initial level under condition of no extraneous supply of NPK fertilizers or manure. The same trend in surface soil layer was also observed in vermicompost treatment $\left(\mathrm{T}_{4}\right)$, but the magnitude of decline was relatively low. However, the plant nutrient status in subsurface soil layer was remained unaltered or, marginally increased. These results are competitive with the findings of Tiwari et al., (2002) who observed the considerable improvement of available $\mathrm{N}, \mathrm{P}$ and $\mathrm{K}$ contents in soil with the application of recommended dose of NPK with FYM @ 15 ton/ha in soybean-wheat system. Similarly, Singh and Pandey (2006) also noticed a significant increase in available $\mathrm{N}, \mathrm{P}$ and $\mathrm{K}$ status in soil over control with the integrated use of $75 \%$
NPK + FYM @ 10 ton/ha in onion. The solubilization of unavailable soil $\mathrm{P}$ by the liberated organic acids from decomposition of vermicompost or by complexation of the cations like $\mathrm{Ca}, \mathrm{Mg}$ and $\mathrm{Al}$ responsible for the fixation of $\mathrm{P}$ might have enhanced the availability of $\mathrm{P}$ in soil from native as well as applied fertilizers (Singh et al., 2011). The higher availability of native soil $\mathrm{K}$ and the status of labile $\mathrm{K}$ in soil due to conjugal application of fertilizer $\mathrm{N}$ and FYM were reported earlier by Singh and Singh (1995).

\section{Leaf nutrient}

The leaf nutrient concentrations of N, P and K at vegetative, flowering and harvesting stages of plant under the influence of inorganic fertilizers and organic manure and their integration was significantly affected over control treatment (Table 7). Maximum concentrations of N, P and $\mathrm{K}$ in leaves at all the plant physiological stages were recorded at 50\% RDF with vermicompost @ 2.5 ton/ha $\left(\mathrm{T}_{3}\right)$. This could be attributed to the optimal supply of NPK nutrients through conjugal use of inorganic fertilizers and organic manure during the growth period which ensured the uniform translocation of nutrients in plant (Singh et al., 2011). The effect of recommended dose of NPK fertilization $\left(\mathrm{T}_{2}\right)$ in increasing the leaf NPK concentrations was, however, inferior to the combined application of inorganic fertilizers and organic manure $\left(\mathrm{T}_{3}\right)$. Higher accumulations of leaf nutrients in flowering 
stage of gladiolus plant might be due to the rapid physiological activity and homeostatic preparation for expensive flowering phase.

In conclusion the above results indicated that application of integrated use of $50 \%$ recommended dose of inorganic fertilizers (50:30:30 NPK kg/ha) with organic manure (vermicompost @ 2.5 ton/ha) markedly improved the growth and floral characters and flower yield of Gladiolus hybridus, besides the maintenance and improvement of soil fertility. Addition of vermicompost or recommended fertilizers dose alone was not enough to meet the plant nutrients requirement. Thus it may be concluded that combined use of half recommended inorganic fertilizers dose with organic manure could be benevolent to the gladiolus growers of lower Gangetic plain of India in achieving the highest yield with improved flower quality and soil fertility status.

\section{References}

Gomez, K.A. and A.A. Gomez. 1984. Statistical Procedures for Agricultural Research. Johnwiley and Sons, Newyork.

Jackson, M.L. 1973. Soil Chemical Analysis. Prentice Hall of India Pvt. Ltd., New Delhi.

Kabir, A.K.M.R., M.H. Iman, M.M.A. Mondal and S. Chowdhury. 2011. Response of tuberose to integrated nutrient management. J. Environ. Sci. Natural Res., 4(2): 55-59.

Okwuagwu, M.I., M.E. Alleh, and I.O. Osemwota. 2003. The effects of organic and inorganic manure on soil properties and yield of okra in Nigeria. African Crop Sci. Congress Proceedings, 6: 390-393.

Padaganur, V.G., A.N. Mokashi and V.S. Patil. 2010. Flowering, flower quality and yield of tuberose as influenced by vermicompost and farmyard manure. Karnataka J. Agri. Sci., 18: 729-734.

Patel, B.M., B.N. Patel and R.L. Patel. 1997. Effect of spacing and fertilizer levels on growth and yield of tuberose (Polianthes tuberosa L.) cv. "Double". J. Appl. Horticulture, 3(1/2): 98-104.

Sharma, G. and P. Singh. 2007. Response of NPK on vegetative growth, flowering and corm production in gladiolus under mango orchard. J. Ornamental Horticulture, 10(2): 52-54.

Singh, R., M. Kumar, S. Raj and S. Kumar. 2013. Effect of integrated nutrient management (INM) on growth and flowering in gladiolus (Gladiolus grandiflorus L.) cv. "White prosperity". Annals of Horticulture, 6(2): 242-251.

Singh, S.R., M.Y. Zargar, G.R. Najar, F.A. Peer and M.I. Ishaq. 2011. Integrated use of organic and inorganic fertilizers with bioinoculants on yield, soil fertility and quality of apple (Malus domestica L.. J. Indian Society of Soil Sci., 59(4): 362-367.

Singh, V. and M. Pandey. 2006. Effect of integrated nutrient management on yield of and nutrient uptake by onion and on soil fertility. J. Indian Society of Soil Sci., 54: 365-367.

Sinha, R. and H. Sunil. 2009. The emerging coeffective and sustainable technology of $21 \mathrm{st}$ century for multiple uses of land management to safe and sustainable food production. Environ. R.J.NY, USA, 3(2-3): $10-19$.

Tiwari, A., A.K. Dwivedi and P.R. Dikshit. 2002. Long term influence of organic and inorganic fertilization on soil fertility and productivity of soybean - wheat system in a vertisol. J. Indian Soc. Soil Sci., 50: 472475 .

\section{How to cite this article:}

Rubina Khanam, Dipa Kundu and Patra, S.K. 2017. Integrated Nutrient Management on Growth, Quality, Yield and Soil Fertility of Gladiolus in Lower Gangetic Plain of India. Int.J.Curr.Microbiol.App.Sci. 6(4): 453-459. doi: https://doi.org/10.20546/ijcmas.2017.604.052 